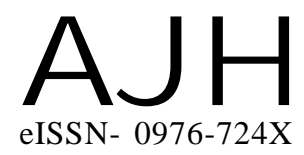

Article history :

Received : 29.09.2016

Revised : 15.11 .2016

Accepted : 26.11.2016

Members of the Research Forum

Associated Authors:

${ }^{1}$ Department of Horticulture,

Agricultural College and Research

Institute, Tamil Nadu Agriculutral

University, MADURAI (T.N.)
Author for correspondence : V. KRISHNAMOORTHY Department of Horticulture, Agricultural College and Research Institute, Tamil Nadu Agriculutral University, MADURAI (T.N.) INDIA
THEASIAN JOURNALOF HORTICULTURE

Volume 11 | Issue 2 | December, 2016 | 387-392 Visit us -www.researchjournal.co.in
RESEARCH PAPER

DOI : 10.15740/HAS/TAJH/11.2/387-392

\section{Per se performance of pumpkin genotypes during Kharif season under southern zone of Tamil Nadu}

\section{S. SAMPATH ${ }^{1}$, V. KRISHNAMOORTHY AND M. ANANTHAN ${ }^{1}$}

ABSTRACT : The present investigation was carried out at Department of Horticulture, Agricultural College and Research Institute, Tamil Nadu Agricultural University, Madurai during Kharif 2015 with 32 pumpkin (Cucurbita moschata Duch. ex. Poir) collected from different parts of Tamil Nadu to identify small fruited high quality genotypes. The genotypes CM-9, CM 3, CM 14 (3.40) recorded more number of primary branches, the highest vine length was recorded in CM18, CM10, CM15 (10.66, 10.50, 9.67m) genotypes. The higher petioles were recorded in CM21, CM18, CM4 (26.63, 24.77, 24.50cm). The higher leaf length was recorded in CM5, CM11, CM1, CM9, CM8, CM23, CM2, CM31 (14.03 to $14.93 \mathrm{~cm})$ genotypes. The leaf breadth was highest in CM15, (22.00), the higher inter nodal length in CM17, (13.53 cm) were recorded. The first male flower in seventh node was observed in CM23, CM1, CM32, CM30, CM4, the first female flower appeared early in CM12, CM26, (20 and $21^{\text {st }}$ node), the days taken for male flowering was ranged from 47.20 to 54.20 days and for flowering ranged from 51.73 to 63.27 days. The early female flowering was recorded in CM29, CM20 and CM17. The lowest sex ratio was recorded in CM30 (13.58). The days taken for fruit maturity less in CM29, CM28 and CM5 (83.47, 87.27 and 87.53 days). The genotypes CM29, CM28 recorded higher number of fruits per plant (4.40 and 3.13) and less fruit diameter (17.80 and $18.33 \mathrm{~cm})$, fruit length $(44.40$ and 49.73 $\mathrm{cm})$, fruit weight $(0.97$ and $1.11 \mathrm{~kg}), 100$ seed weight $(10$ and $15 \mathrm{~g})$. The highest yield per plant was recorded in CM12, CM23, CM3 $(9.48,8.54$ and $7.60 \mathrm{~kg})$. The highest TSS content $\left(10{ }^{\circ} \mathrm{Brix}\right)$ in CM13, acidity (0.78) in CM27, ascorbic acid (10mg) in CM23, moisture content (99\%) in CM30, CM31, beta carotene content in CM29, and CM28 (0.99 and $0.89 \mathrm{mg})$. The CM29 and CM28 genotypes were identified as small fruited type among the genotypes studied.

KEY WORDS : Pumpkin, Cucurbita moschata, Genotypes, Per se performance, Carotene

HOW TO CITE THIS ARTICLE : Sampath, S., Krishnamoorthy, V. and Ananthan, M. (2016). Per se performance of pumpkin genotypes during Kharif season under southern zone of Tamil Nadu. Asian J. Hort., 11(2) : 387-392, DOI : 10.15740/HAS/TAJH/11.2/387-392. 